\title{
ANALISIS PENGARUH PENDAPATAN, TINGKAT PENDIDIKAN, DAN TANGGUNGAN KELUARGA TERHADAP PENGAMBILAN PEMBIAYAAN ARRUM BPKB PADA PT. PEGADAIAN SYARIAH UNIT LANGSA BARO
}

\author{
Zikriatul Ulya \\ Institut Agama Islam Negeri (IAIN) Langsa \\ E-mail: zikriatululya@iainlangsa.ac.id
}

\begin{abstract}
Abstrak
Tujuan penelitian ini adalah untuk mengetahui analisis pengaruh pendapatan, tingkat pendidikan dan tanggungan keluarga terhadap pengambilan pembiayaan Arrum BPKB. Dengan menggunakan metode penelitian kuantitatif, di mana populasinya adalah 235 dan Sampel yang digunakan sebagai subjek dalam penelitian ini sebanyak 70 nasabah. Metode pengambilan sampel dalam penelitian ini menggunakan metode simple random sampling, model analisis data ini menggunakan regresi linear berganda. Berdasarkan hasil analisis dan pengujian hipotesis secara parsial pendapatan berpengaruh positif dan signifikan terhadap pengambilan pembiayaan, variabel tingkat pendidikan juga berpengaruh positif dan signifikan terhadap pengambilan pembiayaan, dan variabel tanggungan keluarga berpengaruh positif dan signifikan terhadap pengambilan pembiayaan. Hasil uji simultan diketahui bahwa variabel pendapatan, tingkat pendidikan dan tanggungan keluarga memiliki pengaruh dan signifikan terhadap pengambilan pembiayaan di Pegadaian Syariah Unit Langsa Baro.
\end{abstract}

Kata Kunci: Pendapatan, Tingkat Pendidikan, Tanggungan Keluarga, Pembiayaan.

\section{Abstract}

The purpose of this study was to determine the analysis of the effect of income, education level and family dependents on the taking of Arrum BPKB financing. By using quantitative research methods, where the population is 235 and the sample used as the subject in this study is 70 customers. The sampling method in this study used simple random sampling method, the data analysis model used multiple linear regression. Based on the results of the analysis and hypothesis testing partially income has a positive and significant effect on the taking of financing, the education level variable also has a positive and significant effect on the taking of financing, and the family dependent variable has a positive and significant effect on the taking of financing. The results of the simultaneous test show that the variables of income, education level and family dependents have a significant and significant influence on taking financing at the Langsa Baro Sharia Unit Pegadaian.

Keywords: Income, Education Level, Family Dependent, Financing.

\section{A. PENDAHULUAN}

PT. Pegadaian Syariah mengeluarkan produk baru yang disebut dengan Arrum. Dengan adanya produk arrum, masyarakat yang ingin mendapatkan dana pembiayaan usaha, tidak serta merta menitipkan barang berupa motor atau mobil di Pegadaian. Akan tetapi, cukup dengan menyerahkan surat BPKB kendaraan sebagai jaminan. Kemudian, PT. Pegadaian akan melakukan studi kelayakan kepada para peminjam dana tentang usaha yang 
dilakukan. Hal ini dilakukan untuk mengurangi resiko dalam pembiayaan kepada masyarakat (Wawancara Dimas Jarod, 2018:12).

Berdasarkan hasil wawancara kepada nasabah Unit Pegadaian Langsa Baro, bahwa mereka mengambil pembiayaan arrum tidak untuk menambah modal usaha, tetapi untuk keperluan lain seperti pendapatan, tingkat pendidikan dan tanggungan keluarga. Dalam interview awal peneliti mendapatkan nasabah yang mengambil pembiayaan pada produk arrum (modal usaha) digunakan sebagai keperluan sehari-hari walaupun nasabah tersebut memiliki usaha.

Selain pendapatan peneliti juga menemukan nasabah yang menggunakan dana pinjaman untuk memenuhi kebutuhan tingkat pendidikan. Selain itu peneliti juga menemukan masalah lain yaitu nasabah yang menggunakan dana pembiayaan modal usaha untuk tanggungan keluarganya. Alasan nasabah tersebut adalah karena pada waktu itu membutuhkan dana cepat untuk pengobatan (musibah tidak terduga) sekalipun selain pada kondisi tersebut pendapatan dari hasil usahanya dapat memenuhi kebutuhan sahari-hari. Sekalipun ada yang mengatakan mereka mengambil pembiayaan dengan tujuan untuk menambah modal usahanya agar usahanya dapat dikembangkan lagi menjadi lebih besar.

Berdasarkan uraian di atas maka tujuan penelitian ini adalah untuk menganalisis pengaruh pendapatan, tingkat pendidikan, dan tanggungan keluarga terhadap pengambilan pembiayaan arrum BPKB pada PT. Pegadaian Syariah Unit Langsa Baro.

\section{B. TINJAUAN PUSTAKA}

\section{Pendapatan}

Pendapatan adalah semua penerimaan baik tunai maupun tidak tunai yang merupakan hasil dari penjualan barang atau jasa dalam jangka waktu tertentu. Menurut Sumardi pendapatan adalah penghasilan berupa uang yang diterima dari gaji atau upah yang diperoleh dari kerja pokok, sampingan, lembur dan dari investasi yakni pendapatan yang diperoleh dari kerja sosial (Dwi Siswanto, 2013:31). Menurut Suyanto (2000:80), bahwa ada 2 (dua) unsur pendapatan. Adapun unsur-unsur pendapatan, yaitu Hasil produksi barang, serta jasa dan imbalan yang diterimanya.

\section{Tingkat Pendidikan}

Pendidikan adalah proses dimana seseorang mengembangkan kemampuan sikap dan bentuk-bentuk tingkah laku lainnya didalam masyarakat, proses sosial dimana orang dihadapkan pada pengaruh lingkungan yang terpilih dan terkontrol sehingga dapat memperoleh perkembangan kemampuan sosial dan kemampuan individu yang optimum (Fuad Ihsan, 2013:4). Menurut Hasbullah (2012:11) bahwa ada 5 (lima) indikator tingkat pendidikan. Adapun indikator tingkat pendidikan meliputi ideologi, sosial ekonomi, sosial budaya, perkembangan IPTEK, dan psikologi.

\section{Tanggungan Keluarga}

Menurut Wirosuhardjo tanggungan keluarga adalah besarnya jumlah tanggungan keluarga akan berpengaruh terhadap pendapatan karena semakin banyaknya jumlah tanggungan keluarga yang ikut makan maka secara tidak langsung akan memaksa tenaga kerja tersebut untuk mencari tambahan pendapatan. (Ibnu Abdi Maulana, 2013:43). Menurut 
kaidah Islam yang dikatakan tanggungan keluarga adalah bahwa setiap kepada keluarga diwajibkan memberi nafkah anggota keluarganya baik makanan dan kebutuhan lainnya dengan cara yang baik (Wilchan Robain, 2012:29).

Menurut Pande Putu Erwin Adiana (2012:39), bahwa ada 2(dua) indikator tanggungan keluarga. Adapun indikator tanggungan keluarga yaitu ekonomi keluarga, dan anggota keluarga yang belum bekerja

\section{Pembiayaan}

Pembiayaan adalah pemberian fasilitas dana untuk memenuhi kebutuhan pihak-pihak yang merupakan defisit unit (Syafi'I Antonio, 2001:160). Pembiayaan berdasarkan prinsip syariah adalah pembiayaan berdasarkan persetujuan atau kesepakatan antara perusahaan pembiayaan dengan pihak lain yang mewajibkan pihak yang dibiayai untuk mengembalikan pembiayaan tersebut dalam jangka waktu tertentu dengan imbalan atau bagi hasil (Andri Soemitra, 2009:383). Menurut Mutmainnah (2012:13) bahwa ada 3 (tiga) indikator pembiayaan. Adapun indikator pembiayaan yaitu pembiayaan modal kerja, pembiayaan investasi, dan pembiayaan konsumsi.

\section{METODE PENELITIAN}

Sifat penelitian ini memakai explanatory. Explanatory adalah penelitian yang menjelaskan hubungan kausal antara variabel-variabel yang mempengaruhi hipotesis, penelitian ini berfungsi menjelaskan, meramalkan, dan mengontrol suatu gejala. Populasi merupakan totalitas dari seluruh unsur yang ada dalam sebuah wilayah penelitian (Azuar Zuliandi, 2013:50). Penentuan besarnya ukuran sampel penelitian ini ditentukan dengan menggunakan teknik probability sampling, Metode memakai Simple Random Samplling (Azuar Zuliandi, 2013:52).

Pengumpulan data dilakukan dengan cara membagikan kuesioner yang sudah dijui validitas dan reabilitasnya. Kuesioner adalah cara pengumpulan data dengan menggunakan pertanyaanpertanyaan tertulis untuk memperoleh informasi dari responden (Hendri Tanjung \& Abrista Devi, 2013:120). Analisis data yang digunakan adalah regresi linear berganda. Uji asumsi klasik regresi berganda bertujuan untuk menganalisis apakah model regresi yang di gunakan dalam penelitian adalah model yang terbaik. Jika model adalah model yang baik, maka data yang dianalisis layak untuk dijadikan sebagai rekomendasi untuk pengetahuan atau untuk tujuan pemecahan masalah praktis.

$$
\begin{aligned}
& \mathrm{Y}=\alpha+\mathrm{b} 1 \times 1+\mathrm{b} 2 \times 2+\mathrm{b} 3 \times 3+\mathrm{e} \\
& \text { Keterangan: } \\
& \mathrm{Y} \quad=\text { Pembiayaan } \\
& \alpha \quad=\text { Konstanta } \\
& \mathrm{b} \quad=\text { Koefisien korelasi ganda } \\
& \mathrm{x} 1 \quad=\text { Pendapatan } \\
& \mathrm{X} 2 \quad=\text { Tingkat Pendidikan } \\
& \mathrm{X} 3 \quad=\text { Tanggungan Keluarga } \\
& \mathrm{e} \quad=\text { Standard Error }
\end{aligned}
$$

Sebelum dilakukan pengujian hipotesis dengan menggunakan analisis regresi, maka diperlukan pengujian asumsi klasik yang meliputi pengujian: Uji normalitas, uji linearitas, uji multikolonearitas, uji heterokedastisitas, dan uji autokorelasi. Pengujian hipotesis dilakukan dengan pengujian statistik sehingga relatif mendekati suatu kebenaran yang diharapkan. 


\section{HASIL DAN PEMBAHASAN}

Uji normalitas digunakan untuk menguji apakah dalam sebuah model regresi, variabel independen (pendapatan, tingkat pendidikan dan tanggungan keluarga) dan dependen (pembiayaan) memiliki distribusi yang normal, dengan cara melihat grafik normal P-P Plot untuk mendeteksi normalitas data (Singgih Santoso, 2000:214). Hasil uji normalitas yang dilakukan ditunjukkan oleh gambar berikut:

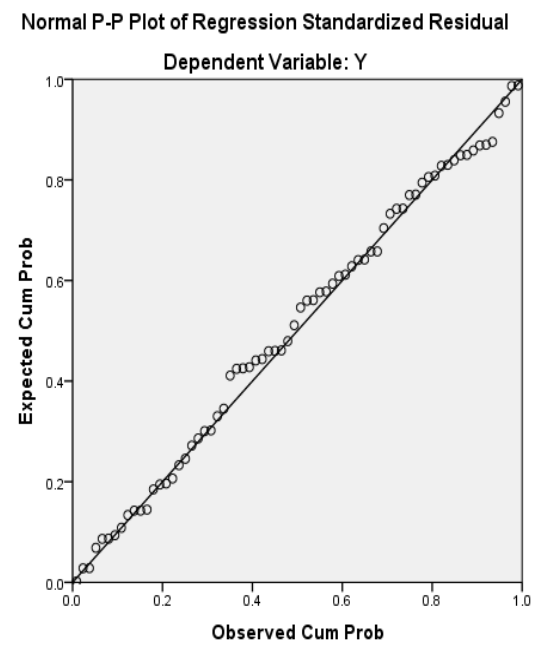

\section{Gambar 1 Hasil Uji Normalitas Data \\ Sumber: Hasil Penelitian, 2018 (Data Diolah)}

Berdasarkan Gambar 1 di atas dapat dilihat bahwa data menyebar disekitar garis diagonal dan mengikuti arah garis diagonal. Hal ini membuktikan bahwa data dipergunakan dalam penelitian ini asumsi normalitas.

Tabel 1 Hasil Uji One-Sample Kolmogorov-Smirnov Test One-Sample Kolmogorov-Smirnov Test

\begin{tabular}{|c|c|c|c|c|c|}
\hline & & $\mathrm{X} 1$ & $\mathrm{X} 2$ & X3 & $\mathrm{Y}$ \\
\hline $\mathrm{N}$ & & 70 & 70 & 70 & 70 \\
\hline \multirow{3}{*}{ Normal Parameters ${ }^{\mathrm{a}, \mathrm{b}}$} & Mean & 14.4429 & 36.7571 & 15.1571 & 22.8000 \\
\hline & Std. Deviation & 2.26271 & 5.01429 & 2.17119 & 2.99565 \\
\hline & Absolute & .108 & .083 & .132 & .129 \\
\hline \multirow[t]{2}{*}{ Most Extreme Differences } & Positive & .088 & .081 & .132 & .112 \\
\hline & Negative & -.108 & -.083 & -.131 & -.129 \\
\hline Kolmogorov-Smirnov Z & & .905 & .693 & 1.101 & 1.077 \\
\hline Asymp. Sig. (2-tailed) & & .386 & .723 & .177 & .196 \\
\hline
\end{tabular}

a. Test distribution is Normal.

b. Calculated from data.

Sumber: Hasil Penelitian, 2018 (Data diolah)

Adapun hasil dari pengujian dengan menggunakan SPSS diketahui bahwa besarnya nilai Kolmogorov-Smirnov adalah:

$\mathrm{X} 1=0,905>0,05$ maka data residual berdistribusi normal.

$\mathrm{X} 2=0,693>0,05$ maka data residual berdistribusi normal.

$\mathrm{X} 3=1,101>0,05$ maka data residual berdistribusi normal.

$\mathrm{Y}=1.077>0,05$ maka data residual berdistribusi normal. 


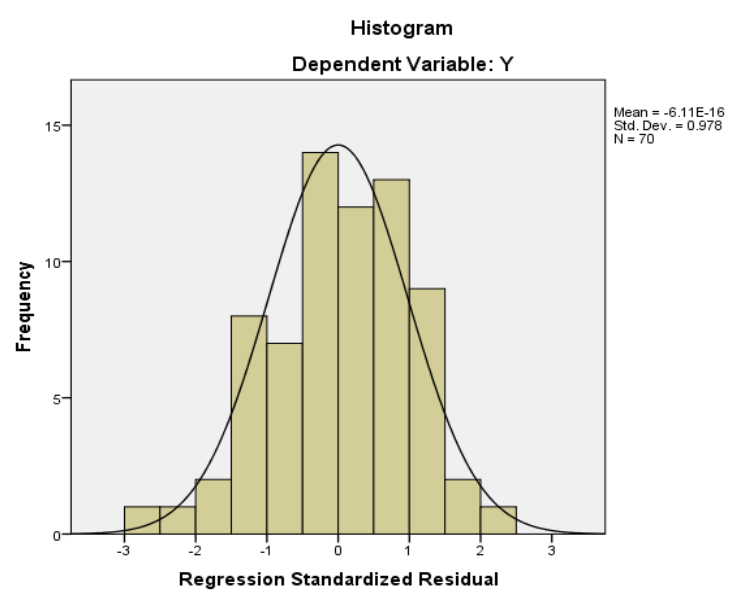

Gambar 2 Grafik Histogram

Sumber: Hasil Penelitian, 2018 (Data Diolah)

Uji linearitas dimaksudkan untuk mengetahui ada tidaknya hubungan secara linear antara variabel dependen terhadap setiap variabel independen yang hendak diuji. Jika nilai signifikan dari deviation from linearity > alpha $(0,05)$ maka nilai tersebut linear $(\mathrm{R}$. Gunawan Sudarmanto, 2004:80).

Tabel 2 Hasil Uji Linearitas

ANOVA Table

\begin{tabular}{|c|c|c|c|c|c|c|c|}
\hline & & & $\begin{array}{l}\text { Sum of } \\
\text { Squares }\end{array}$ & Df & $\begin{array}{l}\text { Mean } \\
\text { Square }\end{array}$ & $F$ & Sig. \\
\hline \multirow{5}{*}{$\begin{array}{l}Y^{*} \\
X 1\end{array}$} & \multirow{3}{*}{$\begin{array}{l}\text { Between } \\
\text { Groups }\end{array}$} & (Combined) & 278.262 & 8 & 34.783 & 6.223 & .000 \\
\hline & & Linearity & 225.777 & 1 & 225.777 & 40.396 & .000 \\
\hline & & $\begin{array}{l}\text { Deviation from } \\
\text { Linearity }\end{array}$ & 52.485 & 7 & 7.498 & 1.342 & .247 \\
\hline & \multicolumn{2}{|c|}{ Within Groups } & 340.938 & 61 & 5.589 & & \\
\hline & \multicolumn{2}{|l|}{ Total } & 619.200 & 69 & & & \\
\hline
\end{tabular}

Sumber: Hasil Penelitian, 2018 (data diolah).

ANOVA Table

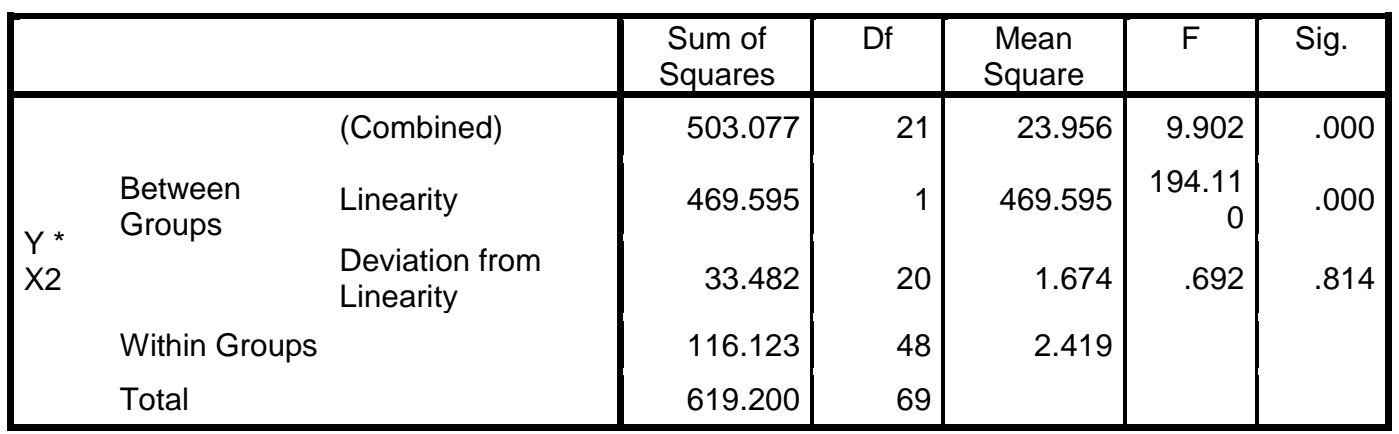

Sumber: Hasil Penelitian, 2018 (data diolah). 


\begin{tabular}{|c|c|c|c|c|c|c|c|}
\hline \multicolumn{8}{|c|}{ ANOVA Table } \\
\hline & & & $\begin{array}{l}\text { Sum of } \\
\text { Squares }\end{array}$ & Df & $\begin{array}{c}\text { Mean } \\
\text { Square }\end{array}$ & $\mathrm{F}$ & Sig. \\
\hline \multirow{5}{*}{$\begin{array}{l}Y^{*} \\
X 3\end{array}$} & & (Combined) & 544.658 & 9 & 60.518 & 48.711 & .000 \\
\hline & Between & Linearity & 535.110 & 1 & 535.110 & $\begin{array}{r}430.71 \\
6\end{array}$ & .000 \\
\hline & Groups & $\begin{array}{l}\text { Deviation from } \\
\text { Linearity }\end{array}$ & 9.548 & 8 & 1.194 & .961 & .475 \\
\hline & Within $\mathrm{Gr}$ & & 74.542 & 60 & 1.242 & & \\
\hline & Total & & 619.200 & 69 & & & \\
\hline
\end{tabular}

Sumber: Hasil Penelitian, 2018 (data diolah)

Berdasarkan tabel di atas, nilai signifikansi deviation from linearity dari hubungan variabel $\mathrm{X}_{1}(0,247), \mathrm{X}_{2}(0,814)$, dan $\mathrm{X}_{3}(0,475)$ terhadap $\mathrm{Y}>0,05$ yang berarti bahwa hubungan kedua variabel independen tersebut dengan variabel dependen adalah linear.

Uji multikolinearitas dapat dilihat dari Variance Inflation Faktor (VIF) dan nilai tolerance. Multikolinearitas terjadi jika nilai tolerancelebih besar dari 0,1 dan nilai VIF lebih kecil dari 10, maka dapat dikatakan bahwa tidak terjadi multikoloniearitas. Adapun hasil dari pengujiannya adalah sebagai berikut:

Tabel 3 Hasil Uji Multikolinearitas

\begin{tabular}{|l|c|c|}
\hline \multicolumn{1}{|c|}{ Variabel independen } & Tolerance & VIF \\
\hline Pendapatan $\left(\mathrm{X}_{1}\right)$ & 0,554 & 1,804 \\
\hline Tingkat Pendidikan $\left(\mathrm{X}_{2}\right)$ & 0,219 & 4,568 \\
\hline Tanggungan Keluarga $\left(\mathrm{X}_{3}\right)$ & 0,295 & 3,394 \\
\hline
\end{tabular}

Sumber: Hasil penelitian, 2018 (Data diolah).

Dari tabel di atas terlihat bahwa semua variabel mempunyai nilai toleransi lebih besar dari 0,1 dan nilai VIF lebih kecil 10, sehingga dapat disimpulkan bahwa model regresi pada penelitian ini tidak terjadi multikolinearitas.

Untuk mendeteksi ada atau tidaknya heteroskedastisitas dapat dilihat pada grafik scatterplot. Model regresi yang baik adalah yang tidak terjadi heteroskedastisitas. Asumsinya adalah:

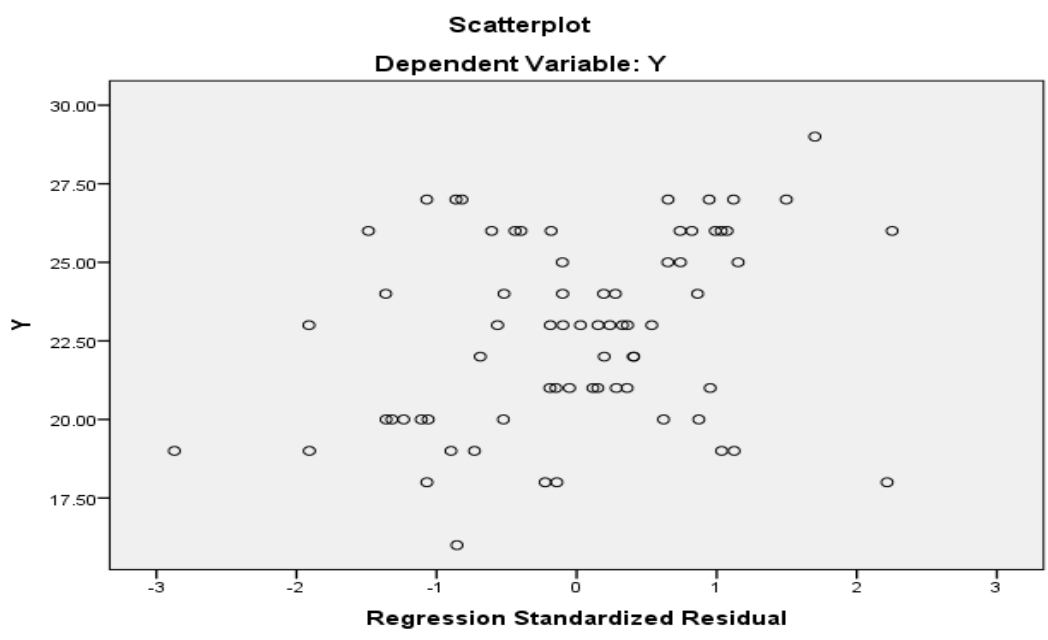

Gambar 3 Hasil Uji Heteroskedastisitas

Sumber: Hasil Penelitian, 2018 (Data Diolah) 
Berdasarkan Gambar di atas, terlihat titik-titik pada Grafik Plot menyebar atau tidak membentuk pola tertentu. Artinya, tidak terjadi heteroskedastisitas pada model regresi yang digunakan, sehingga model regresi layak di pakai untuk menganalisis pengaruh pendapatan, tingkat pendidikan dan tanggungan keluarga terhadap pembiayaan.

Pemeriksaaan autokorelasi menggunakan metode Durbin-Watson, dimana jika nilai DW diantara -2 sampai 2, maka asumsi tidak terjadi autokorelasi.

\section{Tabel 4 Hasil Uji Autokorelasi}

Model Summary ${ }^{\mathrm{b}}$

\begin{tabular}{|l|r|r|r|r|r|}
\hline Model & \multicolumn{1}{|c|}{$\mathrm{R}$} & $\mathrm{R}$ Square & \multicolumn{1}{c|}{$\begin{array}{c}\text { Adjusted } \mathrm{R} \\
\text { Square }\end{array}$} & $\begin{array}{c}\text { Std. Error of the } \\
\text { Estimate }\end{array}$ & Durbin-Watson \\
\hline 1 & $.950^{\mathrm{a}}$ & .903 & .899 & .95176 & 1.816 \\
\hline
\end{tabular}

a. Predictors: (Constant), X3, X1, X2

b. Dependent Variable: Y

Sumber: Hasil Penelitian, 2018 (Data Diolah).

Dari hasil tabel diperoleh nilai DW sebesar 1.816, karena nilai ini berada diantara -2 dan 2, maka asumsi tidak terjadinya autokorelasi.

Analisis ini untuk mengetahui arah hubungan antara variabel independen dan variabel dependen berhubungan positif atau negatif dan untuk memprediksi nilai dari variabel dependen apabila variabel independen mengalami kenaikan atau penurunan.

Tabel 5 Hasil Uji Regresi Linear Berganda

Coefficients $^{\mathrm{a}}$

\begin{tabular}{|c|c|c|c|c|c|c|}
\hline \multirow{2}{*}{\multicolumn{2}{|c|}{ Model }} & \multicolumn{2}{|c|}{ Unstandardized Coefficients } & Standardized & \multirow[t]{2}{*}{$\mathrm{T}$} & \multirow[t]{2}{*}{ Sig. } \\
\hline & & B & Std. Error & Beta & & \\
\hline \multirow{4}{*}{1} & (Constant) & .929 & .952 & & .976 & .333 \\
\hline & $\mathrm{X} 1$ & .199 & .076 & .134 & 2.603 & .011 \\
\hline & $\mathrm{X} 2$ & .120 & .049 & .200 & 2.449 & .017 \\
\hline & X3 & .962 & .097 & .697 & 9.898 & .000 \\
\hline
\end{tabular}

a. Dependent Variable: $\mathrm{Y}$

Sumber: Hasil Penelitian, 2018 (Data Diolah).

Berdasarkan pada Tabel ditunjukkan sebagai berikut: $\mathbf{Y}=\mathbf{0 . 9 2 9}+\mathbf{0 . 1 9 9}_{\mathbf{1}}+$ $\mathbf{0 . 1 2 0 X}_{2}+\mathbf{0 . 9 6 2} \mathbf{X}_{3}$. Nilai signifikan untuk pendapatan sebesar $0,011<$ alpha 0,05 , variabel pendapatan berpengaruh positif dan signifikan terhadap pembiayaan, dengan demikian hipotesis diterima. Nilai signifikan untuk tingkat pendidikan sebesar $0,017<$ alpha 0,05 , variabel proses pendidikan berpengaruh positif dan signifikan terhadap pembiayaan, dengan demikian hipotesis diterima. Nilai signifikan untuk tanggungan keluarga sebesar 0,000 < alpha 0,05, variabel tanggungan keluarga berpengaruh positif dan signifikan terhadap pembiayaan, dengan demikian hipotesis diterima.

Uji t dilakukan untuk menunjukkan seberapa jauh pengaruh variabel independen (pendapatan, tingkat pendidikan dan tanggungan keluarga) secara individual dalam menerangkan variasi variabel dependen (pembiayaan) yang berarti berpengaruh signifikan jika nilai probabilitas yang dihitung $<0,05$ (signifikansi yang ditetapkan) (Mudrajad Kuncoro, 2009:238). 
ARTIKEL

Tabel 6 Hasil Uji t (Uji Parsial)

Coefficients $^{\mathrm{a}}$

\begin{tabular}{|c|c|c|c|c|c|c|}
\hline \multirow[t]{2}{*}{ Mod } & & \multicolumn{2}{|c|}{ Unstandardized Coefficients } & \multirow{2}{*}{$\begin{array}{c}\text { Standardized } \\
\text { Coefficients } \\
\text { Beta }\end{array}$} & \multirow[t]{2}{*}{$\mathrm{T}$} & \multirow[t]{2}{*}{ Sig. } \\
\hline & & B & Std. Error & & & \\
\hline \multirow{4}{*}{1} & (Constant) & .929 & .952 & & .976 & .333 \\
\hline & $\mathrm{X} 1$ & .199 & .076 & .134 & 2.603 & .011 \\
\hline & $\mathrm{X} 2$ & .120 & .049 & .200 & 2.449 & .017 \\
\hline & X3 & .962 & .097 & .697 & 9.898 & .000 \\
\hline
\end{tabular}

a. Dependent Variable: $Y$

Sumber: Hasil Penelitian, 2018 (Data Diolah)

Berdasarkan tabel diatas dapat disimpulkan bahwa pendapatan berpengaruh positif dan signifikan terhadap pengambilam pembiayaan. Dari hasil pengujian secara parsial bahwa pendapatan memperoleh nilai $t_{\text {hitung }}$ sebesar 2.603 (positif) dan nilai probabilitas yang dihitung $0,011<0,05$ probabilitas yang ditetapkan, berarti berpengaruh signifikan dan menerima $\mathrm{H}_{1}$, maka variabel pendapatan berpengaruh positif dan signifikan terhadap pengambilan pembiayaan.

Selain itu, tingkat pendidikan juga berpengaruh positif dan signifikan terhadap pengambilan pembiayaan. Dari hasil pengujian secara parsial bahwa tingkat pendidikan memperoleh nilai $t_{\text {hitung }}$ sebesar 2.449 (positif) dan nilai probabilitas yang dihitung $0,017<$ 0,05 probabilitas yang ditetapkan, berarti berpengaruh signifikan dan menerima $\mathrm{H}_{2}$, maka variabel tingkat pendidikan berpengaruh positif dan signifikan terhadap pengambilan pembiayaan.

Tanggungan keluarga juga berpengaruh positif dan signifikan terhadap pengambilan pembiayaan. Dari hasil pengujian secara parsial bahwa tanggungan keluarga memperoleh nilai $t_{\text {hitung }}$ sebesar 9.898 (positif) dan nilai probabilitas yang dihitung $0,000<0,05$ probabilitas yang ditetapkan, berarti berpengaruh signifikan dan menerima $\mathrm{H}_{3}$, maka variabel tanggungan keluarga berpengaruh positif dan signifikan terhadappengambilan pembiayaan.

Uji F pada dasarnya menunjukkan apakah semua variabel yang dimasukkan dalam model mempunyai pengaruh secara bersama-sama terhadap variabel terikat (pembiayaan).

\section{Tabel 7 Hasil Uji F (Simultan)}

ANOVA $^{\mathrm{a}}$

\begin{tabular}{|rl|r|r|r|r|r|}
\hline Model & & Sum of Squares & Df & Mean Square & F & Sig. \\
\hline \multirow{2}{*}{1} & Regression & 559.414 & 3 & 186.471 & 205.854 & $.000^{\circ}$ \\
& Residual & 59.786 & 66 & .906 & & \\
& Total & 619.200 & 69 & & & \\
\hline
\end{tabular}

a. Dependent Variable: $Y$

b. Predictors: (Constant), X3, X1, X2

Sumber: Hasil Penelitian, 2018 (Data Diolah).

Hasil uji $\mathrm{F}$ pada perhitungan diperoleh $\mathrm{F}$ hitung $=205.854$ dengan nilai $\mathrm{p}$ value $=$ 0.000 (a) $<0,05$ sehingga dapat disimpulkan bahwa hipotesis diterima, yang berarti ada pengaruh secara simultan keseluruhan pendapatan, tingkat pendidikan dan tanggungan keluarga terhadap pengambilan pembiayaan secara signifikan.

Koefisien determinasi $\left(\mathrm{R}^{2}\right)$ yaitu mengukur seberapa jauh kemampuan model dalam menerangkan variasi variabel terikat (Pembiayaan). Koefisien determinasi dalam penelitian ini menggunakan nilai Adjusted $R^{2}$. 
ARTIKEL

Tabel 8 Hasil Uji Determinasi $\left(\mathbf{R}^{2}\right)$

Model Summary ${ }^{\mathrm{b}}$

\begin{tabular}{|l|r|r|r|r|}
\hline Model & $\mathrm{R}$ & R Square & Adjusted R Square & \multicolumn{2}{c|}{$\begin{array}{c}\text { Std. Error of the } \\
\text { Estimate }\end{array}$} \\
\hline 1 & $.950^{\mathrm{a}}$ & .903 & .899 & .95176 \\
\hline
\end{tabular}

a. Predictors: (Constant), X3, X1, X2

b. Dependent Variable: Y

Sumber: Hasil Penelitian, 2018 (Data Diolah).

Pada Tabel menunjukkan nilai adjusted $R^{2}$ sebesar 0,899 yang berarti bahwa $89,9 \%$ variasi nilai pembiayaan yang ditentukan oleh tiga variabel yang berpengaruh terhadap pengambilan pembiayaan yaitu pendapatan, tingkat pendidikan, dan tanggungan keluarga. Sedangkan sisanya $(100 \%-89,9 \%=10,1 \%)$ dijelaskan oleh variabel lain yang tidak dimasukkan dalam model persamaan tersebut di atas.

\section{E. KESIMPULAN}

Hasil pengujian hipotesis pertama yang menyatakan bahwa pendapatan secara langsung berpengaruh terhadap pengambilan pembiayaan Arrum BPKB di Pegadaian Syariah Unit Langsa Baro maka hipotesis di terima. Dari hasil uji t (uji parsial) didapatkan hasil

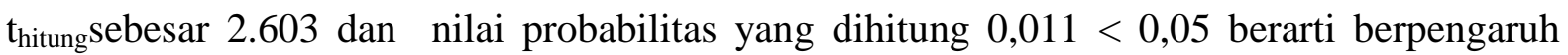
positif dan signifikan terhadap pengambilan pembiayaan Arrum BPKB di Pegadaian Syariah Unit Langsa Baro.

Hasil pengujian hipotesis kedua yang menyatakan bahwa tingkat pendidikan secara langsung berpengaruh terhadap pengambilan pembiayaan Arrum BPKB di Pegadaian Syariah Unit Langsa Baro. Dari hasil uji t (uji parsial) didapatkan hasil $t_{\text {hitung }}$ sebesar 2.449 dan nilai probabilitas yang dihitung $0,017<0,05$ berarti berpengaruh positif dan signifikan terhadap pengambilan pembiayaanArrum BPKB di Pegadaian Syariah Unit Langsa Baro.

Hasil pengujian hipotesis ketiga yang menyatakan bahwa tanggungan keluarga secara langsung berpengaruh terhadap pengambilan pembiayaan Arrum BPKB di Pegadaian Syariah Unit Langsa Baro. Dari hasil uji $t$ (uji parsial) didapatkan hasil $t_{\text {hitung }}$ sebesar 9.898 dan nilai probabilitas yang dihitung $0,000<0,05$ berarti berpengaruh positif dan signifikan terhadap pengambilan pembiayaan Arrum BPKB di Pegadaian Syariah Unit Langsa Baro.

Hasil pengujian keempat menyatakan bahwa pendapatan, tingkat pendidikan dan tanggungan keluarga secara bersama-sama berpengaruh terhadap pengambilan pembiayaan Arrum BPKB di Pegadaian Syariah Unit Langsa Baro. Dari hasil uji F (uji simultan)

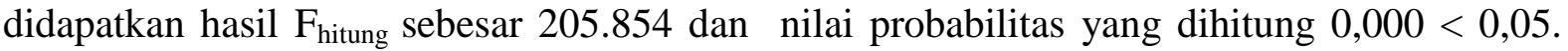
Dengan demikian dapat disimpulkan bahwa pendapatan, tingkat pendidikan dan tanggungan keluarga berpengaruh positif dan signifikan terhadap pengambilan pembiayaan Arrum BPKB di Pegadaian Syariah Unit Langsa Baro.

\section{DAFTAR PUSTAKA}

Adiana, P. P. E., \& Karmini, N. L. (2012). Pengaruh Pendapatan, Jumlah Anggota Keluarga dan Pendidikan Terhadap Pola Konsumsi Rumah Tangga Miskin di Kecamatan Gianyar. E-Jurnal Ekonomi Pembangunan Universitas Udayana (EEP), 1(1), 39-48. 
Antonio, M. S. (2001). Bank Syariah: Dari Teori dan Praktik. Jakarta: Gema Insani.

Asiyah, B. N. (2015). Manajemen Pembiayaan Bank Syariah. Yogyakarta: Kalimedia.

Budisantoso, T., \& Triandaru, S. (2000). Bank dan Lembaga Keuangan Lain. Jakarta: Salemba Empat.

Devi, A., \& Tanjung, H. (2013). Metodologi Penelitian Ekonomi Islam. Jakarta: Gramata Publishing.

Hasbullah. (2012). Dasar-Dasar Ilmu Kependidikan. Jakarta: Raja Grafindo Persada.

Ihsan, F. (2013). Dasar-Dasar Kependidikan. Jakarta: Rineka Cipta.

Kuncoro, M. (2009). Metode Riset Untuk Bisnis dan Ekonomi. Jakarta: Gelora Aksara Pratama.

Mardani. (2015). Aspek Hukum Lembaga Keuangan Syariah di Indonesia. Jakarta: Kencana.

Maulana, I. A. (2013). Analisis Pengaruh Keterampilan, Jumlah Tanggungan Keluarga, Pendapatan dan Pendidikan Terhadap Keluarga Miskin di Desa Sumbergondo. Skripsi Universitas Jember.

Mutmainnah. (2012). Analisis Pembiayaan Arrum PT.Pegadaian Syariah Terhadap Pengembangan Usaha Mikro Kecil. Skripsi UIN Alauddin Makassar.

Robain, W. (2012). Pengaruh Pendapatan, Bagi Hasil, Tanggungan Keluarga dan Religi Terhadap Pola Konsumsi Tenaga Kependidikan di Perguruan Islam Al Ulum Terpadu Medan. Skripsi IAIN Sumatra Utara.

Santoso, S. (2000). Buku Latihan SPSS Statistik Parametik. Jakarta: Elex Media Komputindo.

Siswanto, D. (2013). Faktor-Faktor Yang Mempengaruhi Pendapatan Sopir Angkutan Pedesaan Terminal Arjasa Kabupaten Jember. Skripsi Universitas Jember.

Soemitra, A. (2009). Bank dan Lembaga Keuangan Syari'ah. Jakarta: Prenadamedia Group.

Sudarmanto, R. G. (2004). Analisis Regresi Linear Berganda Dengan SPSS. Bandung: Graha Ilmu.

Sugiyono. (2004). Metode Penelitian Pendidikan. Bandung: Alfabeta.

Suyanto. (2000). Refleksi dan Reformasi Pendidikan di Indonesia Memasuki Milenium III. Yogyakarta: Adicita.

Uhbiyati, N., \& Ahmadi, A. (2003). Ilmu Pendidikan. Jakarta: Rineka Cipta.

Zuliandi, A. (2013). Metodologi Penellitian Kuantitatif Untuk Ilmu-Ilmu Bisnis. Bandung: Citapustaka Media Perintis. 